\title{
In Vivo Antityphoid Activities and Proximate Analysis of Ethanolic Leaf Extracts of Parquetina Nigrescens
}

\author{
Akinyemi O. I. and Dada E. O. \\ Microbiology Department, Federal University of Technology, Akure, Ondo State, Nigeria \\ E-Mail: olugbenga.akinyemi@yahoo.com
}

\begin{abstract}
The study carried out in vivo antibacterial activities of Parquetina nigrescens leaf extracts for the control of typhoid fever. In vivo bioassay was carried out to evaluate the antibacterial and toxicological effects of ethanolic leaf extract of Parquetina nigrescens in Swiss albino mice. Mice infected with the standard inoculum of Salmonella typhi then treated with the extract (group II) showed no signs of infection due to in vivo antibacterial activity of the leaf extract while the mice given standard inoculum of Salmonella typhi without treatment (group I) showed signs of infection. For instance, there was significant $(P<0.05)$ decrease in red blood count (RBC), haemoglobin concentration $(H b)$, packed cell volume $(P C V)$, mean corpuscular volume $(M C V)$ and mean corpuscular haemoglobin $(M C H)$. Also, the results obtained from blood analysis of mice given only the extract (group III) showed that the extract has no deleterious effects on the blood parameters of the mice compare to the result obtained from group IV (control group). Urinalysis result of the mice was found to be positive to biluribin and urobinogen in group I while negative in other groups.

Proximate analysis of ethanolic leaf extract of P.nigrescens showed that carbohydrate, crude protein, ash content, moisture content, ether extract and crude fibre were present in decreasing order.
\end{abstract}

Key words: in vivo, proximate analysis, antityphoid and bioassay.

\section{Introduction}

The success story of chemotherapy lies in the continuous search for new drugs to counter the challenge posed by resistant strains of microorganisms and to determine their toxic effect if any. A large number of plants indeed were used to combat different diseases and known to possess antimicrobial activity. Many studies indicate that in some plants there are many substances such as peptides, unsaturated long chain aldehydes, alkaloidal constituents, some essential oils, phenols and water, ethanol, chloroform, methanol and butanol soluble compounds that can serve as a bactericidal and bacteriostatics (Akinyemi et al., 2013). Researchers have shown that Salmonella typhi has developed resistant to most of the antibiotics used to cure typhoid fever that is why attention is now shifted to the use of antimicrobial agents to cure the disease or to serve as a good source for new antibiotics (Akinyemi et al., 2013).

It is in this search for new antimicrobial agents to combat typhoid disease due to resistant developed by Salmonella typhi to common antimicrobial agents that research to Parquetina nigrescens species which has been reportedly used for the treatment of gonorrhoea, jaundice, rickets and asthma (Schlage et al., 2003) has been made to determine the possible use of the plant to combat typhoid disease and its usefulness in ethnomedicine.

\section{Plant collection and identification}

\section{Materials And Methods}

Fresh Parquetina nigrescens leaves were collected from a compound in Akure metropolis. The leaves were authenticated using the herbarium specimens of the Department of Crop, Soil and Pest Management, Federal University of Technology Akure.

\section{Source and confirmation of bacteria used}

Pure isolate of Salmonella typhi obtained from the stock culture of the Microbiology Department, University Teaching Hospital, Ado-Ekiti, Nigeria into prepared nutrient agar slant. This bacterial strain was further characterized in the Postgraduate Microbiology Laboratory, Federal University of Technology, Akure.

\section{Drying and extraction of the leaf samples}

Parquetina nigrescens leaves were washed with sterile water. The leaves were air dried in room temperature $\left(27 \pm 2^{\circ} \mathrm{C}\right)$ for 3 weeks. The dried leaves were then ground into fine powder by blending in a highspeed Philips model electric blender. They were separately kept in an airtight container to avoid the absorption of moisture.

One hundred and fifty grams $(150 \mathrm{~g})$ of the powdered sample was respectively soaked in one thousand five hundred millimeters $(1500 \mathrm{ml})$ of $70 \%$ ethanol, hot water and cold water as solvents to extract the bioactive 
components. Each container was labeled appropriately and left for 72hours. After which, it was sieved using muslin cloth and then filtered using $0.45 \mu \mathrm{m}$ membrane filter. The filtrates were vaporized to dryness using rotary evaporator (Resona, Germany). The ethanolic, hot and cold water extracts were each transferred into another clean container, packed and placed into a freezer overnight. Frozen extract of each plant was freeze dried in the lyophilizer. This extraction was repeated three times and average percentage yield was calculated. The extracts were preserved in sterile bottles at 40C before use Akinyemi, et al, 2013.

\section{Preparation of crude extract of Parquetina nigrescens}

The method of Akujobi et al., (2004) modified by Akinyemi et al., 2013 was adopted. The crude extract of ethanolic Parquetina nigrescens was reconstituted with 30\% (DMSO) while hot and cold crude extracts were prepared in sterile distilled water to obtain concentrations of $300 \mathrm{mg} / \mathrm{ml}, 250 \mathrm{mg} / \mathrm{ml}, 200 \mathrm{mg} / \mathrm{ml}, 150 \mathrm{mg} / \mathrm{ml}, 100$ $\mathrm{mg} / \mathrm{ml}$, and $50 \mathrm{mg} / \mathrm{ml}$, respectively.

\section{Preparation of standard inocula of Salmonella typhi for in vitro assay}

In preparing the standard inocula of Salmonella typhi for in vitro assay the method described by Andrews (2006) modified by Akinyemi, et al, 2013 was employed. Three isolated overnight cultured colonies were transferred to a tube of sterile saline. The bacterial suspension was compared to the $0.5 \mathrm{McF}$ arland standards against a sheet of white paper on which sharp black lines were drawn. The bacterial suspension was adjusted to be the proper density as the McFarland 0.5 by adding sterile saline or more bacterial growth. Then bacterial suspension was diluted to obtain $10^{6}$ colony forming unit per millimetres $(\mathrm{CFU} / \mathrm{ml})$.

\section{Proximate Analysis}

The standard procedure as outlined in Horwitz (2000) was employed for the determination of the percentage proximate composition of moisture content, ash content, crude protein, carbohydrate, ether extract, and crude fibre. Proximate analysis of ethanolic leaf extract of P.nigrescens showed that carbohydrate, crude protein, ash content, moisture content, ether extract and crude fibre were present.

\section{Moisture Content}

Moisture content of the sample was determined using air oven (A.O.A.C, 1999). The Petri dishes were washed and dried in air oven. The Petri dishes were then transferred into the desiccator and allowed to cool. The weights of the Petri dishes were determined. The sample $(1.0 \mathrm{~g})$ was weighed into the dry Petri dish and the contents were transferred into an oven maintaining a temperature of $\left(105^{\circ} \mathrm{C}\right)$. The contents were allowed to dry at this temperature for 6 hours. The Petri dish with their contents were removed from the oven and placed in the dessicator.

After cooling, the weight was recorded, after drying to a constant weight the percent Moisture content was then calculated on dry weight basis.

$$
\begin{aligned}
& \% \text { Moisture content }=\frac{\text { Weight Loss }(\mathrm{g}) \times 100}{\text { Initial weight }} \\
& \text { Weight of Sample }(\mathrm{g})=\left(\mathrm{W}_{\underline{0}}-\mathrm{W}_{\mathrm{i}}\right) \times 100
\end{aligned}
$$

Where $\mathrm{W}_{0}$ = initial weight of the sample.

$\mathrm{W}_{\mathrm{i}}=$ constant weight of dried sample.

Three determinations were performed and the mean result was recorded as the \% Moisture content.

\section{Total ash content}

Clean crucibles were ignited at $350^{\circ} \mathrm{C}$ for about 15 minutes, cooled in a dessicator and weighed as $\mathrm{W}_{1}$. Each sample $(1.0 \mathrm{~g})$ was transferred into each of the appropriate labeled crucibles and then reweighed as $\mathrm{W}_{2}$. Then, the crucibles with their content were transferred into the muffle furnace at $550^{\circ} \mathrm{C}$ for about 5 hours. After complete ashing, the crucible were allowed to cool in a dessicator and then reweighed as $\mathrm{W}_{3}$. The percentage ash was obtained as follows:

$$
\% \text { Ash }=\frac{\left.\mathrm{W}_{3}-\mathrm{W}_{\mathrm{i}}\right) \mathrm{X}}{\mathrm{W}_{2}-\mathrm{W}_{1}} \frac{100}{1}
$$

Nitrogen determination (Crude Protein)

A $0.5 \mathrm{~g}$ of the sample was weighted into $50 \mathrm{ml}$ micro kjeldahl flask and $5 \mathrm{ml}$ of conc. $\mathrm{H}_{2} \mathrm{SO}_{4}$ with on tablet of kjedahl catalyst were added. The flask was heated on electro thermal heater until samples were completely digested producing a clear light green solution. The flasks were allowed to cool and the solution made up to $50 \mathrm{ml}$ (W1) using distilled water and stored in polyethylene bottle for analysis.

The crude protein in each sample was obtained by multiplying the value of the parentage nitrogen by the conversion factor -6.25 . That is $\%$ crude protein $=\%$ Nitrogen $\times 6.25$. 


\section{Crude fibre content}

Three grams $(3.0 \mathrm{~g})$ of the sample was weighed into separate $500 \mathrm{ml}$ conical flask. $200 \mathrm{ml}$ of $1.25 \%$ $\mathrm{H}_{2} \mathrm{SO}_{4}$ was added to conical flask. The content of the flask was brought to boiling and allowed to boil for 30 minutes on a hot plate. Then, the content of the flask was filtered through poplin cloth and rinsed with hot distilled water. Then the $1.25 \% \mathrm{NaOH}$ (After was added to each, these were brought to boiling and allowed to boil for 30 minutes after which they were filtered through a poplin cloth and rinsed with hot distilled water followed by $10 \% \mathrm{HCI}$, again with hot water and finally with ethanol.

The residues were salvaged into well labeled clean crucibles died in the oven at $105 \mathrm{~V}$ and cooled in a dessicator and reweighed as $\mathrm{W}_{2}$. The crucibles with content were transferred into the muffle furnace at $300^{\circ} \mathrm{C}$ for 1 hour, cooled in a dessicator and reweighed as $\mathrm{W}_{3}$. Then the percentage crude fibre was calculated thus:

$\%$ Crude fibre $=\underline{\mathrm{W}_{2}}-\frac{\mathrm{W}_{3}}{\mathrm{~W}_{1}} \times \underline{100}$

\section{Lipid / Fat content / Ether extract}

The fat content was determined using Soxhlet extractor as described in (A.O.A.C 1999). Three grams $(3.0 \mathrm{~g})$ of the sample was weighed into a thimble and fixed into the Soxhlet extractor with cotton wool. Petroleum ether of boiling point range: $60-80^{\circ} \mathrm{C}$ was used, as the solvent. This was poured into a round hollow flask filled and placed on the heating mantle.

Extraction begins as the solvent refluxed several limes. The extractor continues for about 7 hours after which the Mask was cooled and disconnected. "The thimble containing the sample was dried in the air oven to a constant weight. The weight of the content was subtracted from the weight of sample started with to gel the fat content. The percentage of Fat content was then calculated on wet basis as:

$\%$ Percentage Fat $=\underline{\text { Weight of Oil X } 100}$

$$
\text { Weight of Sample }(g)
$$

\section{Carbohydrate content}

Carbohydrate content of the samples was determined by difference (subtraction of the sum of the moisture, ash, protein, (crude fibre, and at from the total weight of the sample).

\section{Experimental Animals}

Experimental procedures involving the experimental animals and their care were conducted in conformity with international, national and institutional guidelines for Care and Use of Laboratory Animals in Biomedical Research as promulgated by the Canadian Council of Animal Care (CCAC, 1985) and United States National Institutes of Health (AOT, 2001) as described by Adeneye (2008).

Swiss albino mice were obtained from Pharmacy Department, Obafemi Awolowo University, Ile-Ife, Osun State. Nigeria. The rats were fed with standard rat chow (Livestock Feeds, Ikeja, Lagos State, Nigeria) and water ad libitum. The animals were maintained at standard laboratory conditions (12/12 hr dark/light cycle, $20 \pm$ $2{ }^{\circ} \mathrm{C}$ temperature, and $65 \pm 5 \%$ humidity). The Swiss albino mice were acclimatized for seven days before the commencement of the study.

\section{Preparation of the Phosphate Buffer Solution (PBS) and standard inoculum of Salmonella typhi for in vivo assay}

Method described by Rinku et al., (2009) was used. A $0.238 \mathrm{gm}$ of sodium hydrogen phosphate was dissolved in $0.019 \mathrm{gm}$ and $0.019 \mathrm{gm}$ of potassium dihydrogen phosphate and sodium chloride respectively. The mixture was made up to $100 \mathrm{ml}$ with distilled water and $\mathrm{PH}$ was adjusted to 7 .

Standard inocula of Salmonella typhi for in vivo assay were prepared by the method of Rinku et al., (2009). Salmonella typhi was incubated into 1000millimeters of nutrient broth and incubated for 24hours. After incubation the cells were centrifuged and the supernatant was discarded. Pellets were re-suspended in PBS and centrifuged again for four times. The final cell button was resuspended in PBS and adjusted to a concentration of $10^{15} \mathrm{CFU} / \mathrm{ml}$.

\section{Determination of Infectivity Dose 50 (ID (D) $_{50}$}

Method described by Baker and Silverstone, (2006) was used in determining the Infectivity Dose 50 $\left(\mathrm{ID}_{50}\right)$. Twenty four Swiss Albino mice were used to determine the Infectivity Dose 50 (ID 50 ) of Salmonella typhi. The mice were divided into six groups of four mice; each group was infected with different concentrations of Salmonella typhi suspension. The groups were closely observed for seven days. The concentration of Salmonella typhi suspension that produces the signs like unformed stool, weak, scattered fur, falling of hairs and weight loss in $50 \%$ of animals given is taken as the Infectivity Dose 50 (ID ${ }_{50}$ ) of Salmonella typhi. 


\section{Preparation of Crude Extract of Parquetina nigrescens for in vivo assay}

The method of Akujobi et al., (2004) was adopted. The crude extract of ethanolic Parquetina nigrescens was reconstituted in sterile distilled water to obtain concentration of $200 \mathrm{mg} / \mathrm{ml}$.

\section{Treatment}

Animal bioassay was carried out using the method described by Jang-Gi-Choi, et al., 2009. Mice were divided into four groups:

Group I: Mice infected with Salmonella typhi

Group II: Mice infected with Salmonella typhi then treated with ethanolic leaf extracts of Parquetina nigrescens

Group III: Mice given ethanolic extract of Parquetina nigrescens only

Group IV: Mice given basal diet and sterile distilled water (Control)

Each treatment group contained five mice. Throughout the acclimatization period, mice were provided with water that contained streptomycin $(5 \mathrm{mg} / \mathrm{ml})$ in order to reduce the level of facultative anaerobic bacteria that normally colonize the mouse intestine. Groups I and II were exclusively inoculated using gavage needle orally with one millimetre $(1 \mathrm{ml})$ of standard inoculums of S. typhi. One hour after infection, animals in group II were orally administered one millimetres $(1 \mathrm{ml})$ of two hundred milligrams per millimetres $(200 \mathrm{mg} / \mathrm{ml})$ of the ethanolic extract of Parquetina nigrescens once daily (using gavage needle), group III was orally administed one millimetre $(1 \mathrm{~m})$ of two hundred milligrams per millimetres $(200 \mathrm{mg} / \mathrm{ml})$ of the ethanolic extract of Parquetina nigrescens (using gavage needle) once in a day for three days before infected with one millimetre $(1 \mathrm{ml})$ of standard inoculums of S. typhi to determine the prophylaxis of ethanolic extract of Parquetina nigrescens . Group IV was given one millimetres $(1 \mathrm{ml})$ of $200 \mathrm{mg} / \mathrm{ml}$ of ethanolic extract of Parquetina nigrescens daily throughout the experiment to determine immunomodulatory and toxicological effects of ethanolic leaf extract of Parquetina nigrencens at $200 \mathrm{mg} / \mathrm{ml}$. Group V was given sterile distilled water and serves as the control. All the mice were observed for seven days

\section{Relative Organ Weight}

Method described by Stanley et al., (2005) was used to determine the relative organ weight of the mice. On seventh day of the infection, all the animals were euthanized by exsanguinations under chloroform anaesthesia. Different organs namely the heart, liver, lungs, spleen, kidneys and testes were carefully dissected out and weighed in grams (absolute organ weight). The relative organ weight of each animal was then calculated as follows:

\begin{tabular}{|c|c|c|c|}
\hline Relative Organ Weight & & Absolute organ weight (g) & X 100 \\
\hline
\end{tabular}

\section{Haematological Assay}

The mice were sacrificed and their blood was collected by cervical collection into labelled EDTA bottles. The various analyses as described by (Baker, 2006) were carried out on the blood of the mice as follows:

\section{Erythrocyte Sedimentation Rate (ESR)}

A wintrobe tube was filled to the top 0 mark and one end of it blocked with plastacine. It was stand in an upright position undisturbed for 60minutes. The distance of the fall of red cells in it was read and expressed as the millimetres ( $\mathrm{mm})$ fall in hour as the ESR.

\section{Packed Cell Volume (PCV)}

Blood collected into anticoagulant bottle and a capillary tube was filled up to $75 \%$ (3/4) of its length and placed in the microhaematocrit centrifuge with the sealant at the outer end and centrifuged at $12,000 \mathrm{rpm}$ for 5 minutes. The result was read as percentage of packed red cells to total volume of whole blood using a haematocrit reader.

\section{Red Blood Cell count (RBC)}

The blood sample was diluted 1:200 and mixed properly. A $0.02 \mathrm{ml}$ of the blood was pipette into $4 \mathrm{ml}$ of diluting fluid in a bijou bottle and washed thoroughly by alternately drawing up and expelling the diluting fluid. A fine Pasteur pipette was used to fill the counting chamber and counted using a counter under x40 objective. 


\section{White Blood Cell count (WBC)}

The blood was first diluted in ratio 1: 20 and $0.05 \mathrm{ml}$ of the blood pipetted into $0.95 \mathrm{ml}$ of diluting fluid. A little portion was charged into the counting chamber and observed using x10 objective to count the white cells/cubic mm.

\section{Haemoglobin (Hb)}

Using mouthpiece, sucker and a $0.02 \mathrm{ml}$ pipette, blood was withdrawn and expelled into 4ml Drabkin's solution in a tube. The tube was stoppered, mixed and allowed to stand for 5minutes for full colour development. A standard blood sample of known haemoglobin concentration was prepared. Using a green (624) filter, the calorimeter was set to zero using plain Drabkin's solution as a blank. The readings of the sample and the standard were taken and the result calculated as follows: sample haemoglobin concentration= Reading of test $\mathrm{x}$ standard haemoglobin concentration

$$
\text { Reading of standard }
$$

\section{White Blood Cell Differential (WBC Differntial)}

These are divided into granulocytes and agranulocytes. The granulocytes are further divided into three which are neutrophils, eosinophils and basophils. These were counted after staining with Giesma stain and their numbers recorded. The agranulocyte is equally further divided into two, which are lymphocytes and monocytes.

\section{Mean Cell Heamoglobin Concentration (MCHC)}

This expresses the concentration of haemoglobin in the red cells, as compared to the concentration of haemoglobin in $100 \mathrm{ml}$ of whole blood. This is calculated as follows:

MCHC $=\underline{\text { Heamoglobin } X 100}$

PCV

\section{Mean Cell Heamoglobin (MCH)}

This expresses the amount of haemoglobin in one red cell expressed as picograms (pg). And this was calculated by dividing the haemoglobin content in 100nl of blood by the number of millions of red blood cells per cubic millimetre and multiplied by 10 .

\section{Mean Cell Volume (MCV)}

This expresses the average red cell volume, measured in cubic microns and this was calculated by multipling the PCV by 10, and dividing by the number of millions of red cells per cubic millimetres

\section{Urinalysis}

The urine macroscopy was carried out using a combi 9 urine test strip which measured the value of protein, blood, urobinogen, biluribin, protein, nitrite, ketone, ascorbic acid, glucose and $\mathrm{PH}$ in urine (Monica, 2006).

\section{Statistical analysis}

The data obtained were subjected to analysis of variance (ANOVA) and the Duncan's New Multiple Range test was used to separate the means. The level of significance was considered at $\mathrm{P}<0.05$.

\section{Results And Discussions}

The Proximate analysis of ethanolic extract of Parquetina nigrescens result expressed in (Table-1) showed that Carbohydrate was present at largest percentage of $45.82 \%$ this might be as a result that plants store most of the manufactured food as carbohydrate inform of glucose, followed by crude protein $21.91 \%$, ash content 12.44 , ether extract $6.9 \%$, moisture content was $8.36 \%$ because the leaf has been dried while crude fibre has the lowest value of $4.5 \%$.

In determining the infectious dose of Salmonella typhi, (Table-2) it takes up to 48 hours before the disease set in this in line with Prescott, 2005 which states that incubation period of Salmonella typhi can be 48 hours and more. Mice infected without treatment, showed the signs of infection- furring hair, unformed stool, weakness, lost of weight and diarrhea as shown in Table-3 and on plate-1 respectively. They shed more S.typhi in their stool as shown in Table-4. Urinalysis result showed that urobilinogen and billuribin were present in the urine of the group infected with Salmonella typhi without treatment. This might be as a result of inflammation of the liver. However, these were tested negative in the treated group. Urinalysis parameters were found to be normal suggesting a possible killing of the pathogens by the extract. This may also be as a result of presence of phytoreactants in the plant (Akinyemi et al., 2013). Packed cell volume (PCV), Heamoglobin 
concentration( $\mathrm{Hb}$ ), Red blood cell (RBC), White blood cell (WBC), Mean corpuscular haemoglobin (MCH), Mean corpuscular volume (MCV) were found to differ in rats that were administered with ethanolic extract of Parquetina nigrescens after infected with Salmonella typhi and those that were not treated. These corroborate the work of Jang-Gi Choi et al., (2009) on in vitro and in vivo antibacterial activity of Punica granatum Peel Ethanol Extract against Salmonella and stated that the oral administration of Punica granatum Peel Ethanol Extract had antibacterial effect on Swiss albino mice infected with Salmonella.

The unexpected reduction in WBCs in untreated group against expectation as more WBCs were suppose to be produced during infection in readiness for phagocytosis might be explained in terms of the physiology of S.typhi that known to produce coagulase enzyme (Jawetz et al., 2004). The enzyme helps in blood clotting by converting soluble fibrin in the blood to insoluble fibrinogen. This might have form a protective coat around the cell of the bacterium and protects it from phagocytosis (Oladunmoye et al., 2007). However, neutrophil count was reduced and lymphocyte higher in the infected but untreated animals than the treated animals. The reduction in neutrophil count may be as a result of possible migration into tissue in response to the infection from pathogenic organism. Neutrophil is the most abundant circulating granulocyte and their granules contain numerous microbial molecules and when a chemotactic factor is produced as a result of infection or injury, in an intracellular site, these cells enter the tissues (Weir and Stewart, 1999).

However the trend was reversed with lymphocytes that remain higher in untreated animals than treated animals after infection with S.typhi. This can be explained in terms of lymphocytes remaining the only freely circulating leukocyte after migration of neutrophil into tissues during infection. The lower values in the treated mice are probably due to the in vivo antibacterial activity of the extract against pathogen. The hepatosplenomegaly, falling of hairs, passing of unformed stools observed in untreated animals was as a result of S.typhi infection (Monica 2006). Whereas the normal size of liver and spleen obtained in treated group compare with control is due to the in vivo antibacterial activity of the extract against S.typhi. There was no significant difference in ESR values in all the groups compare to control. This is because ESR is not usually affected in typhoid fever (Monica, 2006).

The PCV and haemoglobin level were higher in infected but treated mice than those infected without treatment with ethanolic leaf extract of Parquetina nigrescens. Acute inflammation from most pathogenic microorganisms results in haemolysis which is manifested in lower heamoglobin level and PCV (Kumarnsit et al., 2006). The higher values of these haematological indices in rats treated with the extract after infection from the pathogen can be due to their inability to cause haemolysis resulting from the anti-inflammatory potentials inherent in the plant extract (Oladunmoye et al., 2007).

The result of this project also showed that ethanolic leaf extract of Parquetina nigrescens has no toxicological effect on the blood parameters of Swiss albino mice given the extract only as shown by haematology results as there is no observable change in the value of the blood parameters compare to that of the control group rather there is increase in WBC and lymphocytes of the mice compare to control group. This could be attributed to the immunomodulatory effect of the extracts. There was no significant difference $(\mathrm{P}<0.05)$ in monocyte parameter in the mice given the extract only compare to the mice in control group. This is because monocytes stay for 8 hours in the blood after production before transporting to the parts of the body where they take residents and refered to as macrophages (Prescott et al., 2008). Though, the mechanism of action of the extract was not studied, the increase in WBC and lymphocytes values as shown in mice given the extract only could be as a result of high carbohydrate content as shown by the result of proximate analysis. This is in line with the work of (Wang, et al., 2001) and (Assinewe, et al., 2002) who separately worked on Immunomodulating activity of CVT-E002, a proprietary extract from North American ginseng (Panax quinquefolium) and reported that extractable polysaccharides of Panax quinquefolius L. (North American ginseng) root stimulate WBC and lymphocytes production. Also the increase in WBC and lymphocytes could be attributed to ascorbic acid present in ethanolic extract of Parquetina nigrescens as shown by phytochemical screening result (Akinyemi et al., 2013). This is in agreement with the report that supplemental vitamin C may help to enhance leukocyte activity and mobilization (Linder, 1991, Heuser, et al., 1997, Vojdani, et al., 1993). Vitamin $\mathrm{C}$ has been clearly linked to the modulation of immune function, particularly in the context of novel research showing improved cognitive status in patients with neurodegenerative disorders (Martin, 2003). Also histopathology findings in the study suggested that the extract was relatively non-toxic. (Histopathology results not shown)

\section{Conclusions}

The in vivo antibacterial activity of Parquetina nigrescens extract might be related to the action of its antibiotic compounds or to the presence of metabolic toxins. This suggests that these components may also provide antibacterial activity against Salmonella and provide a plausible explanation for the higher antityphoid activity of the ethanolic leaf extract of Parquetina nigrescens. On the other hand, the unknown minor components present have not been elucidated in terms of their activity. Further studies then need to be done. In 
the future, thorough investigation is needed to better ascertain the toxicity, maximum duration of use and pharmacologically, its antiinflammatory, analgesic, antioxidant, hypoglacaemic, anti-diabetic and anticarcinogenic properties can also be investigated.

\section{References}

[1]. Acute Oral Toxicity (OECD Test Guideline 425) (AOT). (2001). Statistical Programme

[2]. (AOT425StatPPgm), version 1.0. Available online at http://www. oecd. org/ OECD/ pages/home/ displaygeneral/ 0,3380,ENdocument-524-nodirectorate-no-24-6775-8,FF.html

[3]. Adeneye, A.A. (2008). Haematopoetic effect of methanol seed extract of Citrus paradisi Macfad (grape fruit) in Wistar rats. Biomedical Research, 19 (1): 23-26.

[4]. Akinyemi, O. I. and Dada, E. O. (2013). Phytochemical screening and antityphoid properties of ethanolic leaf extracts of Parquetina nigrescens. ARPN Journal of Agricultural and Biological Science vol. 8 (10):732-739.

[5]. Akujobi, C.O., Ogbulie, J.N. and Uchegbu, U.N. (2006). Antibacterial activities and preliminary phytochemical screening of vernonia amygdalina and citrus aurantifolia. Nigeria Journal of Microbiology, 20(1): 649-654.

[6]. Andrews, J.M. (2006). BSAC standardized disc susceptibility testing method (version 5). Journal of Antimicrobial Chemotherapy, 58:511-529.

[7]. Association of Official Analytical Chemists (A.O.A.C.). (1999), Official Methods of Analysis, 15th ed., Washington, DC.

[8]. Assinewe, V.A., Amason, J.T., Aubry, A., Mullin, J., and Lemaire, I. (2002). Extractable polysaccharides of Panax quinquefolius L. (North American ginseng)root stimulate TNF alpha production by alveolar macrophages. Phytomedicine, 9: 398-404.

[9]. Baker, F.J. and Silverstone, R.E. (2006). Medical Laboratory Science. $8^{\text {th }}$ edition. Chris Publisher, Washinton D.C., USA. P 447.

[10]. Canadian Council of Animal Care. Guide to the handling and Use of experimental animals. Ottawa: Ont. 1984; 2 United States NIH publication, 1985. no. $85-23$.

[11]. Heuser, G. and Vojdani, A. (1997). Enhancement of natural killer cell activity and T and B cell function by buffered vitamin C in patients exposed to toxic chemicals: the role of protein kinase-C. Immunopharm Immunotox., 19: 291-312.

[12]. Horwitz, W. (2000). Official Methods of Analysis of AOAC International, 17th Edition. USA. pp. 30-59.

[13]. Jang-Gi Choi, Ok-Hwa Kang, Young-Seob Lee, Hee-Sung Chae, You-Chang Oh, Obiang-Obounou Brice, Min-

[14]. Obounou Brice, Min-San Kim, Dong-Hwan Sohn, Hun-Soo Kim, Hyun Park, Dong-Won Shin, Jung-Rae Rho, and Dong-Yeul Kwon (2009). In Vitro and In Vivo Antibacterial Activity of Punica granatum Peel Ethanol Extract against Salmonella. Hindawi Publishing Corporation Evidence-Based Complementary and Alternative MedicineVolume 2011, Article ID 690518, 8 pages doi:10.1093/ecam/nep105.

[15]. Jawetz, E., J. Melnick and Adeiberg, E.A. (2004). Medical Microbiology. $23^{\text {rd }}$ Edn., McGraw-Hill Companies, pp:202-254.

[16]. Kurmarnsit, E., Keawpradub, N. and Nuankaew, W. (2006). Acute and long term effects of alkaloid extract in Mitryagra speciosa on food and water intake and body weight of rats. Fitoterapia, 77:339-345.

[17]. Linder, M. (1991). Nutritional Biochemistry and Metabolism with Clinical Applications. $2^{\text {nd }}$ ed.

[18]. Appleton \& Lange: Norwalk, CT.

[19]. Martin, A. (2003). Antioxidant vitamins E and C and risk of Alzheimer's disease. Nutr Rev, 61:69-73.

[20]. Monica, C.( 2006).District Laboratory Practise in Tropical Countries. Part 2, Low Price Edn., Cambridge University United Kingdom, pp: 136.

[21]. Oladunmoye, M.K. and Osho I.B. (2007). Antiinflammatory Activity of Ethanolic Leaf Extract from Carica papaya in Rats Orogastrically Dosed with Salmonella and Staphylococcus aureus. Journal of Applied Science, 2 (4): 447 - 452.

[22]. Prescott, L.M., Harley, J.P. and Klein, D.A. (2008). General microbiology $7^{\text {th }}$ ed.Mc Graw Hill, New York, USA. Pp 1096.

[23]. Schlage, C. (2002). Medical Plants of the Wasambas (Tanzania): Documentation and Ethropharmaological evalution Plant Biology, 2: 83-92.

[24]. Stanley O. A., Florence C. N., David D. A., Gloria A. A., Sunday D., Kazeem S. I., Matthew D., Patrick E. C.N., Charles W. and Karynius G. (2005). Toxicity studies in rats fed nature cure bitters. African Journal of Biotechnology Vol. 4 (1): pp. $72-78$.

[25]. Vojdani, A. and Ghoneum, M. (1993). In vivo effect of ascorbic acid on enhancement of human natural killer cell activity. Nutr Res., 13: 753-64.

[26]. Wang, M., Guilbert, L.J., Ling, L., Li, J., Wu, Y. and Xu, S. (2001). Immunomodulating activity of CVT-E002, a proprietary extract from North American ginseng (Panax quinquefolium) J Pharm

[27]. Pharmacol., 53: 1515-23.

[28]. Weir, D.M. and Stewart, J. (1999). Immunology. Churchill Livingstone. $8^{\text {th }}$ Edn., pp: 362.

Table 1: Proximate analysis of ethanolic extract of Parquetina nigrescens in percentage

\begin{tabular}{|l|l|}
\hline Components & Percentage \\
\hline Crude protein & 19.91 \\
Carbohydrate & 5.90 \\
Ether extract & 45.82 \\
Moisture content & 12.36 \\
Ash content & 3.57 \\
Crude fibre & 12.44 \\
\hline
\end{tabular}

Table 2: Infectivity dose 50 of Salmonella typhi on albino rats

\begin{tabular}{|l|l|l|l|l|}
\hline Type of infection & Microorganism & $\begin{array}{l}\text { Infectivity dose 50 } \\
(\mathrm{cfu} / \mathrm{ml})\end{array}$ & $\begin{array}{l}\text { Duration for infection to } \\
\text { set in }\end{array}$ & Animal weight(g) \\
\hline Single & S.typhi & $5 \times 10^{14}$ & $48-72$ hours & $80-90$ \\
\hline
\end{tabular}


Table 3: General observation of the mice during treatment

\section{Keys}

\begin{tabular}{|llllll|}
\hline & & & & \\
Days & Group I & Group II & Group III & Group IV & Group V \\
\hline & & & & \\
1 & A, NSI, FS & A, NSI, FS & A, NSI, FS & A, NSI, FS & A, NSI, FS \\
2 & R, FS & A, NSI, FS & A, NSI, FS & A, NSI, FS & A, NSI, FS \\
3 & US, W, MS & A, NSI, FS & A, NSI, FS & A, NSI, FS & A, NSI, FS \\
4 & R, US, FH,MS & A, FS, FH & A, NSI, FS & A, NSI, FS & A, NSI, FS \\
5 & R, US, FH,MS & A, FU, NSI & A, NSI, FS & A, C, FS & A, NSI, FS \\
6 & R, W, FH,MS & A, FU, NSI & R, US, MS & A, C, FS & A, NSI, FS \\
7 & UF, A, FH & A, FU, NSI & R, US, MS & A, C, FS & A, NSI, FS \\
\hline
\end{tabular}

A - Active, C - Constipation, FS - Formed Stool, NSI - No Sign of Infection,

R - Restlessness, US - Unformed Stool, W- Weak, FH - Failing of hairs, MS- Mucoid stool

Table 4: Effects of treatment with ethanolic extract of Parquetina nigrescens on feacal shedding of Salmonella typhi $\left(\mathrm{cfu} \mathrm{g}^{-1}\right)$ by mice

\begin{tabular}{|lllll|}
\hline & & & & \\
Days & Group I & Group II & Group III & Group IV \\
\hline 0 & 0 & 0 & 0 & 0 \\
1 & $4 \times 10^{6}$ & $2 \times 10^{5}$ & 0 & 0 \\
2 & $7 \times 10^{6}$ & $4 \times 10^{5}$ & 0 & 0 \\
3 & $3 \times 10^{8}$ & $1 \times 10^{5}$ & 0 & 0 \\
4 & $2 \times 10^{8}$ & $2 \times 10^{4}$ & $2 \times 10^{4}$ & 0 \\
5 & $3 \times 10^{6}$ & $2 \times 10^{3}$ & $6 \times 10^{6}$ & 0 \\
6 & $4 \times 10^{5}$ & $1 \times 10^{2}$ & $4 \times 10^{6}$ & 0 \\
7 & $2 \times 10^{3}$ & $2 \times 10$ & $3 \times 10^{5}$ & 0 \\
\hline
\end{tabular}

Plate 1a

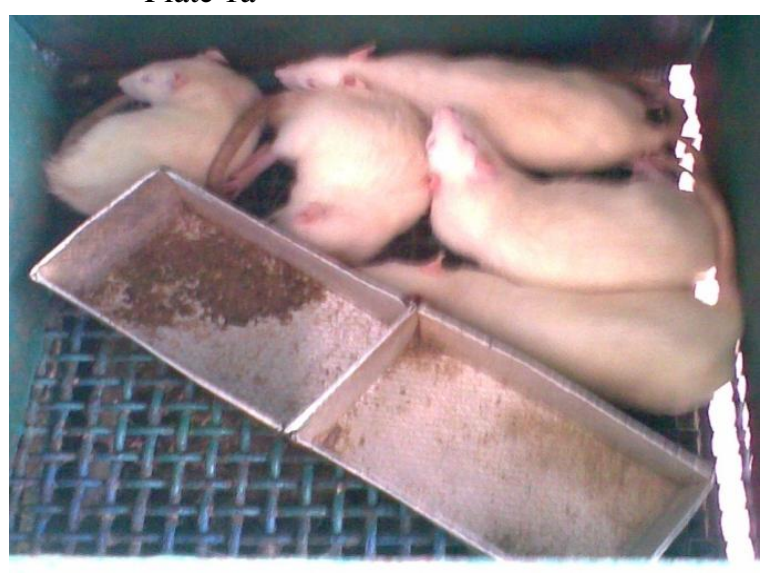

Plate 1c

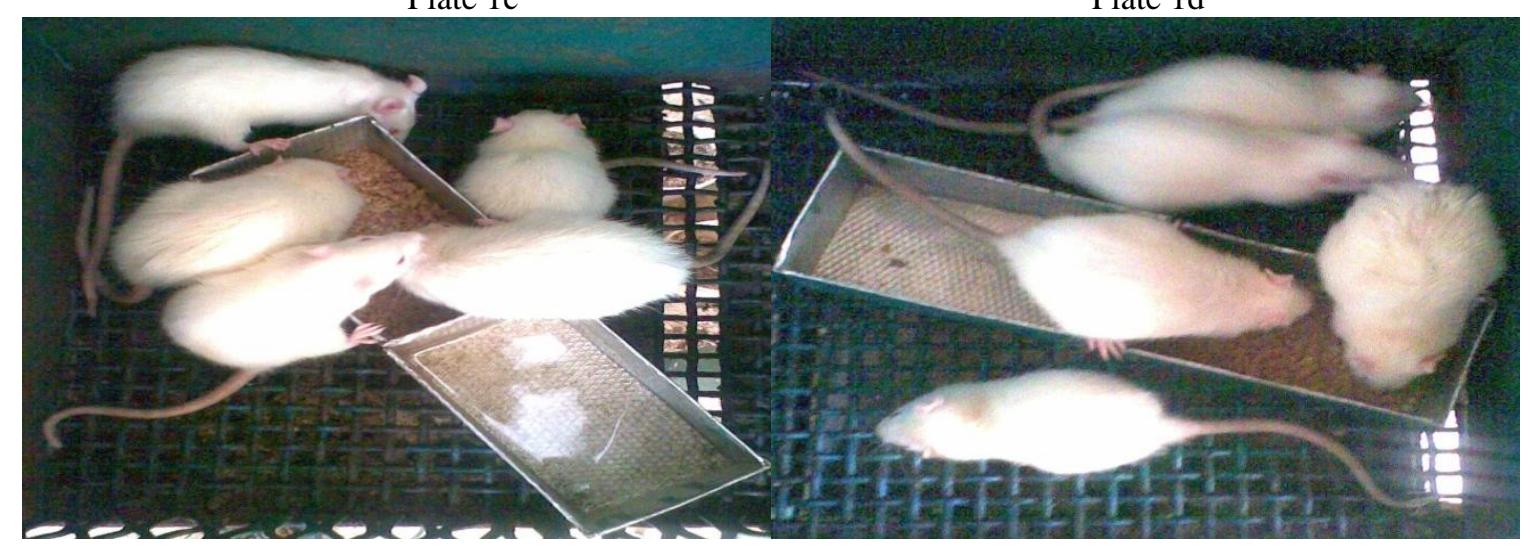

Plate $1 \mathrm{~b}$

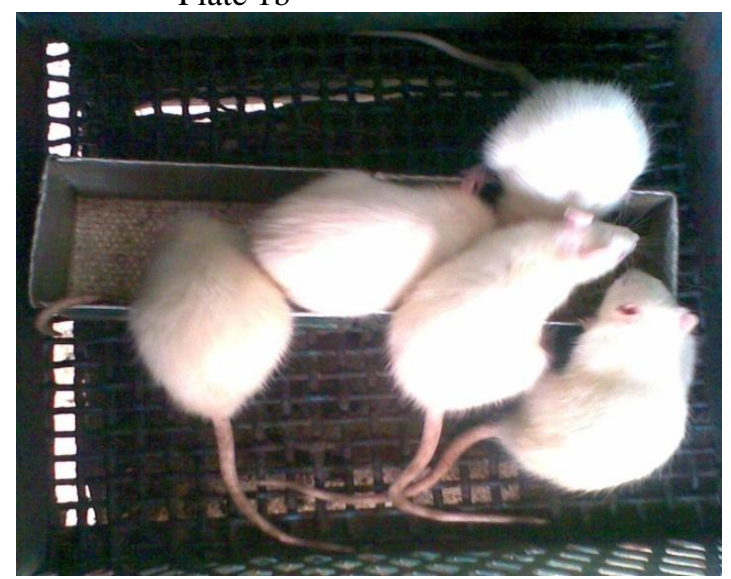

Plate 1d

Plate 1

Plate 1: Signs shown by the mice during treatment 
Keys

Plate 1a: Mice infected with S.typhi only. Plate 1b: Mice infected with S.typhi then treated with extract. Plate 1c: Mice given extract only. Plate 1d: Mice given basal diet only (Control)

Note: The significant features on Plate 1a include loss of appetite, dull, weakness of the mice. The mice in Plate $1 \mathrm{~b}, 1 \mathrm{c}$ and $1 \mathrm{~d}$ were healthy.

Table 5: Effects of ethanolic extract of Parquetina nigrescens on the relative organ weights of the mice $(\mathrm{g} / 100 \mathrm{~g}$

\begin{tabular}{|l|l|l|l|l|l|}
\multicolumn{9}{|c|}{ body weight $)$} \\
\hline Organs & Group I & Group II & Group III & Group IV & Group V \\
\hline Liver & $5.7 \pm 0.36^{\circ}$ & $5.0 \pm 0.45$ & $5.7 \pm 0.30^{\circ}$ & $4.2 \pm 0.45$ & $4.5 \pm 0.05$ \\
Kidneys & $1.1 \pm 0.09$ & $1.0 \pm 0.07$ & $1.1 \pm 0.05$ & $1.0 \pm 0.06$ & $1.1 \pm 0.15$ \\
Kidneys & $1.1 \pm 0.09$ & $1.0 \pm 0.07$ & $1.1 \pm 0.05$ & $1.0 \pm 0.06$ & $1.1 \pm 0.15$ \\
Spleen & $0.9 \pm 0.10^{\circ}$ & $0.9 \pm 0.10^{\circ}$ & $0.8 \pm 0.05^{\circ}$ & $0.7 \pm 0.08$ & $0.6 \pm 0.06$ \\
Heart & $0.7 \pm 0.06$ & $0.6 \pm 0.07$ & $0.6 \pm 0.03$ & $0.6 \pm 0.08$ & $0.7 \pm 0.01$ \\
\hline
\end{tabular}

${ }^{\circ} \mathrm{P}<0.05$ significantly different from control

Table 6: Effect of ethanolic extract of Parquetina nigrenscens on the urine of mice

\begin{tabular}{|l|l|l|l|l|}
\hline Parameters & Group I & Group II & Group III & Group IV \\
\hline PH & 6 & 5 & 5 & 6 \\
Glucose & - & - & - & - \\
Ascorbic acid & - & ++ & ++ & - \\
Ketone & - & - & - & - \\
Nitrite & - & - & - & - \\
Protein & - & - & - & - \\
Biluribin & ++ & - & - & - \\
Urobinogen & +++ & - & - & - \\
Blood & - & - & - & \\
\hline
\end{tabular}

+: present,++ : present moderately, +++ : present abundantly, - : absent.

Table 7: Effect of ethanolic extract of Parquetina nigrescens on haematological parameters of mice

\begin{tabular}{|l|l|l|l|l|}
\hline Parameters & Group I & Group II & Group III & Group IV \\
\hline & & & & \\
PCV (\%) & $35.8 \pm 4.26^{\mathrm{a}}$ & $42.6 \pm 2.07$ & $41.0 \pm 1.41$ & $42.4 \pm 2.30$ \\
$\mathrm{Hb}(\mathrm{g} / \mathrm{dL})$ & $11.7 \pm 1.16^{\mathrm{a}}$ & $14.2 \pm 0.77$ & $13.5 \pm 0.63$ & $13.9 \pm 1.00$ \\
$\mathrm{RBC}(\mathrm{x} \mathrm{10} / \mu \mathrm{L})$ & $6.4 \pm 0.66^{\mathrm{a}}$ & $8.1 \pm 1.37$ & $8.6 \pm 1.85$ & $8.0 \pm 1.82$ \\
Mono. (\%) & $4.2 \pm 1.09^{\mathrm{a}}$ & $6.2 \pm 1.30$ & $6.2 \pm 1.64$ & $5.2 \pm 1.30$ \\
Lymph. (\%) & $67.8 \pm 1.48^{\mathrm{b}}$ & $63.0 \pm 4.52$ & $67.2 \pm 3.11^{\mathrm{b}}$ & $62.6 \pm 3.36$ \\
Neutr. (\%) & $25.8 \pm 1.30^{\mathrm{a}}$ & $28.2 \pm 3.96$ & $29.6 \pm 1.81$ & $29.4 \pm 3.04$ \\
Eos. (\%) & $1.8 \pm 0.83$ & $1.8 \pm 0.83$ & $1.6 \pm 0.54$ & $2.2 \pm 0.83$ \\
Bas. (\%) & $0.4 \pm 0.54$ & $0.8 \pm 0.44$ & $0.6 \pm 0.54$ & $0.6 \pm 0.50$ \\
WBC(x 10 $\left.\mathrm{mm}^{3}\right)$ & $10.2 \pm 1.17^{\mathrm{a}}$ & $12.96 \pm 1.23$ & $14.2 \pm 0.90^{\mathrm{b}}$ & $12.5 \pm 2.07$ \\
ESR(mm/h) & $1.3 \pm 0.67$ & $1.0 \pm 0.00$ & $1.2 \pm 0.44$ & $1.1 \pm 0.54$ \\
MCHC (\%) & $32.9 \pm 1.28$ & $33.4 \pm 0.33$ & $32.9 \pm 0.68$ & $32.9 \pm 0.81$ \\
MCH(pg) & $20.9 \pm 1.28^{\mathrm{a}}$ & $25.4 \pm 1.39$ & $23.5 \pm 0.96$ & $24.9 \pm 1.79$ \\
MCV & $71.6 \pm 8.53^{\mathrm{a}}$ & $85.2 \pm 4.14$ & $82.0 \pm 2.82$ & $84.8 \pm 4.60$ \\
\hline
\end{tabular}

$\mathrm{PCV}=$ Packed cell volume, $\mathrm{Hb}=$ Haemoglobin concentration, $\mathrm{RBC}=\mathrm{Red}$ blood count

Mono.= Monocyte, Neutr. $=$ Neutrophil, Eos. $=$ Eosinophil, Bas. $=$ Basophil

$\mathrm{WBC}=$ White blood cell, $\mathrm{ESR}=$ Erythrocyte sedimentation range

$\mathrm{MCHC}=$ Mean corpuscular haemoglobin concentration, $\mathrm{MCH}=$ Mean corpuscular haemoglobin

$\mathrm{MCV}=$ Mean corpuscular volume, Lymph.= Lymphocytes, $\mathrm{n}=4$

a and $^{\mathrm{b}}$ represent significant decrease and increase at $\mathrm{p}<0.05$ respectively, when compared to control values (Group V) 